\title{
EDITORIAL
}

\section{UNIVERSIDADES DE VERDAD: EL DESAFÍO PENDIENTE}

El modelo de educación superior chilena exhibe logros importantes en materia de aumento de la cobertura de la formación de pregrado. En efecto, las instituciones universitarias, tanto privadas como públicas, han sido capaces de aumentar la cantidad de sus vacantes en función de una demanda creciente por educación universitaria. Sin embargo, la creación de conocimiento avanzado, es una tarea pendiente para el sistema.

La investigación y desarrollo, a través de la creación de conocimientos avanzados, es una fuente fundamental de progreso y desarrollo económico en una trayectoria de largo plazo (Lundvall, 2003; Dowrick, 2002). Los estudios sobre este particular, muestran que la investigación y desarrollo tiene altas tasas de retorno económico, sobre el 20\% (por ejemplo, Lichtenberg y Siegel, 1991; Nadiri, 1993) y social sobre 50\% (por ejemplo, Lichtenberg y Van Pottelsberghe, 1996; Frantzen, 2000).

La creación de nuevo conocimiento en Chile descansa fundamentalmente en las instituciones universitarias. Sin embargo, los indicadores sobre esta materia muestran importantes carencias:

- Chile invierte sólo en torno al $0,7 \%$ de su producto interno bruto en ciencia y tecnología, en tanto que en el promedio de los países de la Organización para la Cooperación Económica y Desarrollo (OECD) dicha cifra asciende a 2,26\% (OECD, 2004).

- Chile tiene escaso número de profesionales científicos e investigadores, lo que significa que sólo 1 de cada 10.000 miembros de la fuerza de trabajo está dentro de esta categoría, en tanto que los países de la OECD tienen una cifra de 61.5 profesionales científicos e investigadores por cada 10.000 miembros de la fuerza de trabajo (Brunner y Elacqua, 2003).

- Chile ocupa el lugar 35 entre 104 países en el índice tecnológico del Foro Económico Mundial (World Economic Forum, 2004) y el lugar 37 entre 72 países en el índice de adelanto tecnológico del Programa de las Naciones Unidas para el Desarrollo (PNUD, 2001).

- La cantidad de doctores formados en Chile, la cantidad de patentes concedidas en los Estados Unidos, y la participación de Chile en la generación de conocimiento científico a nivel mundial (Fundación Nacional para la Ciencia, National Science Foundation, 2000; 2002) muestran a un país que le falta mucho por progresar en materia de ciencia y tecnología.

- Las empresas participan escasamente del esfuerzo en investigación y desarrollo, por ejemplo en el período 1998-2000 la participación de las empresas llega sólo al 18.0\% del total de recursos invertidos (Brunner y Elacqua, 2003).

En esta perspectiva, la creación de ciencia y tecnología es un desafío central para Chile. El enfrentar dicho desafío requiere de decisiones de política pública y de capacidades en el sistema universitario. Ciertamente, las dimensiones de la capacidad competitiva de las instituciones universitarias en materia de investigación y desarrollo debe considerar múltiples variables. 
Rev. Fac. Ing. - Univ. Tarapacá, vol. 13 Nº 2, 2005, pp. 9-10

\section{EDITORIAL}

\section{AUTHENTIC UNIVERSITIES: A PENDING CHALLENGE}

The Chilean higher education model can be credited with significant recent accomplishments, especially when it comes to improving the coverage of undergraduate enrollments. Indeed, in the last decade, public and private universities have significantly boosted openings for the growing number of students who pursue a university degree. Nevertheless, the creation of new knowledge is still a pending task within the system.

Development through advanced knowledge is a fundamental source of progress and economic development for a long range trajectory (Lundvall 2003, Dowrick 2002). Research shows that scientific investigation and development can yield high economic as well as social revenues, which can increase the former up to 20\% (Lichtenberg and Siegel, 1991, Nadiri, 1993) and up to 50\% for the latter (Lichtenberg and Van Pottelsberghe, 1996; Frantzen, 2000).

In Chile, advanced knowledge creation is mainly generated in universities. Nevertheless, benchmarks show that the country scantly invests in this activity, as shown by the following:

- Chile spends a mere $0.7 \%$ of its GNP in science and technology, whereas countries belonging to the Economic Cooperation and Development Organization (ECDO) invest an average of $2.26 \%$ (ECDO, 2004).

- In Chile, the number of professionals engaged in scientific research is small. Only one in 10,000 members of the work force falls into this category, whereas in the countries that belong to the ECDO, the number of scientific professionals and scholars engaged in research is 65.5 for every 10,000 (Brunner and Elacqua, 2003).

- Chile has been ranked $35^{\text {th }}$ among 104 countries by the World Economic Forum Index and $37^{\text {th }}$ among 72 countries by the United Nations Program for Development (UNPD, 2001).

- The small number of professionals receiving a Ph.D. from Chilean universities, as well as minimal Chilean participation in the generation of high level scientific knowledge, not to mention the limited number of patents granted to Chilean inventors, suggests that the country is far behind in the creation of scientific knowledge and the development of new technologies (National Science Foundation, 2000, 2002).

- Investment in research and development by private companies is also insufficient, as seen thorough the three year period between 2000 and 2002, when investments by private companies accounted for 18\% (Brunner and Elacqua, 2003).

In light of these statistics, the development of science and technology is a must for Chile, a challenge that will demand making decisions regarding public policies as well as assessing the capability of the Chilean university system's ability to fulfill future needs.

A university's competitiveness in research and development must consider multiple variables. A natural starting point is to consider research and development projects submitted by universities for consideration by the Chilean National Commission of Science and Technology (CONICYT). It is also important to consider research published in scientific journals recognized by the Institute for Scientific Information (ISI), as well as the Scientific Electronic Library Online (SciELO). 
Within this context, it is important to note that in 2002, 100\% of technology transference projects approved by the Chilean National Fund for Encouragement of Development of Science and Technology (FONDEF) were originated in public universities. Similarly, 99.2\% of the research and development projects sponsored by FONDEF were carried out by public universities.

On the other hand, if we consider the ISI and SciELO publications submitted by Chilean academics between 2001 and $2003,98 \%$ of the articles in the ISI index and $87.2 \%$ of the works found in SciELO correspond to research originated in public universities.

Based on these facts, it is possible to say that meaningful research is done at long established Chilean state universities grouped by the Consejo de Rectores (Chilean University Presidents Council) and, as revealed by statistics, research by private counterparts is minimal, and has yet to be proven.

In Chile, the concept of "university" is closely related to academic research, which, strictly speaking, is done by few traditional universities. Many private institutions of higher education are institutions whose spreading of knowledge is not based on newly own created knowledge.

The consolidation of true universities, that go beyond professional training programs, is a pending task in Chilean higher education, an enterprise that is the most relevant in the process of successfully integrating Chile into the society of knowledge.

Dr. Emilio Rodríguez Ponce

Rector Universidad de Tarapacá

Arica, Chile 
Una buena aproximación (proxy) de dichas variables dice relación con los proyectos de investigación científica y tecnológica e investigación aplicada de la Comisión Nacional de Ciencia y Tecnología, así como las publicaciones del Institute for Scientific Information (ISI) y las publicaciones de Scientific Electronic Library Online (SciELO), reconocidas por el Ministerio de Educación y el Consejo de Rectores como publicaciones relevantes.

Es así que, de los proyectos FONDEF de Transferencia Tecnológica, emprendidos en el año 2002, el 100\% correspondió a universidades públicas (Consejo de Rectores). Similarmente de los proyectos FONDEF de Investigación y Desarrollo del mismo año, el 99.2\% correspondió a universidades del Consejo de Rectores de Chile.

En relación con los proyectos FONDECYT del año 2003, el 94.7\% corresponde a proyectos liderados por las universidades públicas.

Por otra parte, si consideramos las publicaciones ISI y SciELO, en el periodo $2001-2003$, veremos que el 98\% de las publicaciones ISI corresponden a universidades del Consejo de Rectores y un $87.2 \%$ de las publicaciones SciELO corresponde a universidades del Consejo de Rectores.

Es indudable que la investigación que se realiza en Chile se sustenta en las universidades del Consejo de Rectores, principalmente en las universidades tradicionales.

La capacidad de las universidades privadas para incursionar en el campo de la investigación no está probada y su participación en el total de investigaciones científicas y publicaciones relevantes es mínima.

El concepto de universidad se liga indisolublemente con la investigación de estas instituciones.

En consecuencia, en Chile sólo una cifra menor de instituciones son estrictamente universidades y muchas instituciones son centros de formación superior, cuya difusión de conocimiento carece de fundamento en la creación de conocimiento avanzado.

La consolidación de universidades de verdad, que vayan más allá de la formación de profesionales, es una tarea pendiente del sistema chileno. Dicha tarea es de la mayor relevancia para insertar a nuestro país exitosamente en la sociedad del conocimiento.

\author{
Dr. Emilio Rodríguez Ponce \\ Rector Universidad de Tarapacá \\ Arica, Chile
}


Rev. Fac. Ing. - Univ. Tarapacá, vol. 13 Nº 2, 2005, pp. 9-10

\section{EDITORIAL}

\section{AUTHENTIC UNIVERSITIES: A PENDING CHALLENGE}

The Chilean higher education model can be credited with significant recent accomplishments, especially when it comes to improving the coverage of undergraduate enrollments. Indeed, in the last decade, public and private universities have significantly boosted openings for the growing number of students who pursue a university degree. Nevertheless, the creation of new knowledge is still a pending task within the system.

Development through advanced knowledge is a fundamental source of progress and economic development for a long range trajectory (Lundvall 2003, Dowrick 2002). Research shows that scientific investigation and development can yield high economic as well as social revenues, which can increase the former up to 20\% (Lichtenberg and Siegel, 1991, Nadiri, 1993) and up to 50\% for the latter (Lichtenberg and Van Pottelsberghe, 1996; Frantzen, 2000).

In Chile, advanced knowledge creation is mainly generated in universities. Nevertheless, benchmarks show that the country scantly invests in this activity, as shown by the following:

- Chile spends a mere $0.7 \%$ of its GNP in science and technology, whereas countries belonging to the Economic Cooperation and Development Organization (ECDO) invest an average of $2.26 \%$ (ECDO, 2004).

- In Chile, the number of professionals engaged in scientific research is small. Only one in 10,000 members of the work force falls into this category, whereas in the countries that belong to the ECDO, the number of scientific professionals and scholars engaged in research is 65.5 for every 10,000 (Brunner and Elacqua, 2003).

- Chile has been ranked $35^{\text {th }}$ among 104 countries by the World Economic Forum Index and $37^{\text {th }}$ among 72 countries by the United Nations Program for Development (UNPD, 2001).

- The small number of professionals receiving a Ph.D. from Chilean universities, as well as minimal Chilean participation in the generation of high level scientific knowledge, not to mention the limited number of patents granted to Chilean inventors, suggests that the country is far behind in the creation of scientific knowledge and the development of new technologies (National Science Foundation, 2000, 2002).

- Investment in research and development by private companies is also insufficient, as seen thorough the three year period between 2000 and 2002, when investments by private companies accounted for 18\% (Brunner and Elacqua, 2003).

In light of these statistics, the development of science and technology is a must for Chile, a challenge that will demand making decisions regarding public policies as well as assessing the capability of the Chilean university system's ability to fulfill future needs.

A university's competitiveness in research and development must consider multiple variables. A natural starting point is to consider research and development projects submitted by universities for consideration by the Chilean National Commission of Science and Technology (CONICYT). It is also important to consider research published in scientific journals recognized by the Institute for Scientific Information (ISI), as well as the Scientific Electronic Library Online (SciELO). 
Within this context, it is important to note that in 2002, 100\% of technology transference projects approved by the Chilean National Fund for Encouragement of Development of Science and Technology (FONDEF) were originated in public universities. Similarly, 99.2\% of the research and development projects sponsored by FONDEF were carried out by public universities.

On the other hand, if we consider the ISI and SciELO publications submitted by Chilean academics between 2001 and $2003,98 \%$ of the articles in the ISI index and $87.2 \%$ of the works found in SciELO correspond to research originated in public universities.

Based on these facts, it is possible to say that meaningful research is done at long established Chilean state universities grouped by the Consejo de Rectores (Chilean University Presidents Council) and, as revealed by statistics, research by private counterparts is minimal, and has yet to be proven.

In Chile, the concept of "university" is closely related to academic research, which, strictly speaking, is done by few traditional universities. Many private institutions of higher education are institutions whose spreading of knowledge is not based on newly own created knowledge.

The consolidation of true universities, that go beyond professional training programs, is a pending task in Chilean higher education, an enterprise that is the most relevant in the process of successfully integrating Chile into the society of knowledge.

Dr. Emilio Rodríguez Ponce

Rector Universidad de Tarapacá

Arica, Chile 